American Journal of Animal and Veterinary Sciences 6 (2): 65-68, 2011

ISSN 1557-4555

(C) 2011 D. Khonyoung et al., This open access article is distributed under a Creative Commons Attribution

(CC-BY) 3.0 license

\title{
No Damage of Dietary Dried Fermented Ginger Diet without Antibiotics on Growth Performance in Broilers Reared in Tropical Area
}

\author{
${ }^{1}$ Duddoa Khonyoung, ${ }^{1}$ Koh-en Yamauchi, ${ }^{2}$ Tonglian Buwjoom, \\ ${ }^{2}$ Buaream Maneewan, ${ }^{2}$ Narin Thongwittaya and ${ }^{1}$ Toyota Masanori \\ ${ }^{1}$ Department of Applied Biological Science, \\ Laboratory of Animal Science, Faculty of Agriculture, \\ Kagawa University, Miki-cho, Kagawa-ken, Japan \\ ${ }^{2}$ Faculty of Animal Science and Technology, \\ Maejo University, Chiang Mai, Thailand
}

\begin{abstract}
Problem statement: The experiment was carried out to determine whether the dietary Dried Fermented Ginger (DFG) has no affecting damage on broiler growth performance and can also be applicable in tropical and subtropical area using basal diets without antibiotics. Approach: Three hundred and fifty 7-d-old Arbor Acres broiler chicks were divided into one basal diet group (control) and 6 experimental groups. The basal diets were adequately formulated, but not added with antibiotics. Among the 6 DFG groups, 3 groups were fed each basal diet supplemented with DFG at $0.25(0.25 \mathrm{~S}), 0.5(0.5 \mathrm{~S})$ and $1 \%(1 \mathrm{~S})$ levels from 7-42 days of age (starter groups). The remaining 3 DFG groups were fed the starter basal diet until 21 days of age. At 22 days of age, they were switched to finisher diet supplemented with DFG at $0.25(0.25 \mathrm{~F}), 0.5(0.5 \mathrm{~F})$ and $1 \%(1 \mathrm{~F})$, from 22-42 days of age (finisher groups). Results: Feed intake, body weight gain and feed efficiency were not significantly different among the groups ( $>0.05$ ). However, when the body weight gain of the control was expressed as an index of 100 , the body weight gain index of the DFG groups was better than the control except the $0.25 \mathrm{~S}$ groups. Compared to the body weight gain index of the starter groups, they showed the better index. The values of feed efficiency were also better in all the experimental groups than in the control. Conclusion: The present results suggest that DFG can apply to tropical and subtropical area as a natural supplementation without antibiotics and it is better to supplement to basal diet during finisher stage (from 22 days old).
\end{abstract}

Key words: Dried fermented ginger, growth performance, finisher groups, feed efficiency, weight gain, starter basal, determine whether, adequately formulated, without antibiotics, poultry production, promoting qualities, natural supplementation

\section{INTRODUCTION}

Chemical disinfectants are used to prevent pathogens and disease, thereby improving the production of animals for meat. However, dietary antibiotics have elevated the feed cost in poultry production and continued use of dietary antibiotics has induced the development of drug residues in the animal body (Butaye et al., 2001), imbalance in normal microflora (Andremont, 2000) and drugresistant pathogens (Castanon, 2007). Furthermore, the use of such chemicals contaminates the environment. As a result, alternatives are being developed to enhance physiological functions and to reduce environmental pollution through the use of natural ingredients. Ginger rhizome (Zingiber officinale Roscoe, Zingiberacae) is widely used in food condiments and medical herb around the world. Their compound has properties that improve the functioning of the immune system, anti-tumorigenic, anti-inflammatory, anti-apoptosis, antihyperglycemia, anti-lipidemic (Ali et al., 2008) and antifungal activities (Atai et al., 2009). Recently, instead of antibiotics, we reported that DFG possesses growth-promoting qualities in broiler chicken (Incharoen et al., 2010) and egg-productionpromoting qualities in layer chickens (Incharoen and Yamauchi, 2009). However, these results were basic data obtained in temperate region of Japan using small number of chickens.

In tropical and subtropical areas, stress caused by high environmental temperatures is widely recognized

Corresponding Author: Koh-en Yamauchi, Department of Applied Biological Science, Laboratory of Animal Science, Faculty of Agriculture, Kagawa University, Miki-cho, Kagawa-ken, 761-0795, Japan Tel/Fax: +81-87-891-3053 
as one of the primary problems in poultry production (Maak et al., 2003; Aberra et al., 2005). Feed intake and feed efficiency of animal was decreased in high temperature and in violent case heat stress caused death (Darcan et al., 2007). As the ginger has strong flavor and is known to have pyrogenicity (Eldershaw et al., 1992; Fujisawa et al., 2005), it have to examine whether this pyrogenicity of ginger in DFG inhibit the growth performance of the broilers when they were reared in tropical and subtropical areas. Therefore, for the next step it was important to determine whether the DFG has no damaging effects on broiler growth performance and can also be applicable in tropical and subtropical area using basal diets without antibiotics.

This study was designed to demonstrate the effects of dietary DFG on the growth performance of 350 broiler chickens raised in a tropical area and fed DFG from the starter stage or the finisher stage using diets without antibiotics.

\section{MATERIALS AND METHODS}

Three hundred and fifty one-day-old Arbor Acres strain broiler chicks of both sexes were provisioned from a commercial hatchery. At 7 days of age, chicks of similar weights were divided into 7 treatments with 5 replicates of 10 birds. The basal mash diets for the starter (7-21 days of age) and finisher (22-42 days of age) phases were adequately formulated (NRC, 1994) (Table 1), but not treated with antibiotics. Each basal diet was supplemented with DFG (Table 2) at 0 (control group), $0.25,0.5$ and $1 \%$ levels.

Among the 6 DFG groups, 3 groups started the feeding experiment at levels of 0.25 ( $0.25 \mathrm{~S}$ group), 0.5 (0.5 S group) and $1 \%$ (1 S group) at 7 days of age until
42 days of age (starter groups). The remaining 3 groups were fed the starter basal diet until 21 days of age; from 22 days of age, they were switched to the finisher diet, supplemented with DFG at 0.25 (0.25 F group), 0.5 (0.5 $\mathrm{F}$ group) and $1 \%$ (1 F group) from $22-42$ days of age (finisher groups). Feed and water were provided $a d$ libitum, as was $24 \mathrm{~h}$ light. Body weight and feed intake were measured weekly. At 14 and 28 days of age, all chicks were vaccinated against Infectious Bronchitis (IB) and Newcastle Disease (ND).

Statistical analysis: All data were analyzed using analysis of variance in Completely Randomized Design (CRD). Duncan's Multiple Range Test (DMRT) was used to compare sets of means by using the Statistical Package for the Social Sciences (SPSS) Version 13.

\section{RESULTS}

The feed intake, body weight gain and feed efficiency of the chickens in the starter groups and finisher groups were not significantly different among the groups ( $p>0.05)$ (Table 3$)$. However, when the body weight gain of the control was expressed as an index of 100 , the body weight gain index of the DFG groups were better than the control except the $0.25 \mathrm{~S}$ group. Compared to the body weight gain index of the starter groups (98.24 in the $0.25 \mathrm{~S}$ group, 101.81 in the $0.5 \mathrm{~S}$ group and 100.85 in $1 \mathrm{~S}$ group) the finisher groups showed better indices: 102.77 in the $0.25 \mathrm{~F}$ group, 104.48 in the $0.5 \mathrm{~F}$ group and 103.79 in the $1 \mathrm{~F}$ group.

The values for feed efficiency were also better in all the experimental groups than in the control.

Table 1: Composition of the experimental diets

\begin{tabular}{|c|c|c|c|c|c|c|c|c|}
\hline \multirow[b]{3}{*}{ Ingredient } & \multicolumn{8}{|c|}{ Level of ginger (\%) } \\
\hline & \multicolumn{4}{|c|}{ 7-21 days old } & \multicolumn{4}{|c|}{ 22-42 days old } \\
\hline & 0 & 0.25 & 0.5 & 1 & 0 & 0.25 & 0.5 & 1 \\
\hline Ground corn & 51.300 & 51.700 & 51.450 & 50.900 & 59.290 & 58.840 & 58.680 & 58.080 \\
\hline Soybean meal ( $46 \% \mathrm{CP})$ & 33.000 & 32.000 & 32.000 & 32.000 & 27.500 & 27.750 & 27.650 & 27.700 \\
\hline Fish meal $(61 \% \mathrm{CP})$ & 6.100 & 6.800 & 6.800 & 6.800 & 6.100 & 6.000 & 6.000 & 6.000 \\
\hline Rice bran oi & 16.400 & 6.200 & 6.200 & 6.200 & 54.700 & 4.750 & 4.750 & 4.800 \\
\hline Dicalcium phosphate & 0.850 & 0.700 & 0.700 & 0.700 & 0.300 & 0.300 & 0.300 & 0.300 \\
\hline Limestone & 1.100 & 1.100 & 1.100 & 1.100 & 1.250 & 1.250 & 1.250 & 1.250 \\
\hline DL-Methionine & 0.150 & 0.150 & 0.150 & 0.150 & 0.015 & 0.015 & 0.015 & 0.015 \\
\hline Salts & 0.350 & 0.350 & 0.350 & 0.350 & 0.350 & 0.350 & 0.350 & 0.350 \\
\hline Premix & 0.750 & 0.750 & 0.750 & 0.750 & 0.500 & 0.500 & 0.500 & 0.500 \\
\hline \multicolumn{9}{|l|}{ Calculated analysis } \\
\hline $\operatorname{ME}\left(\mathrm{kcal} \mathrm{kg}^{-1}\right)$ & 3205.000 & 3205.000 & 3205.000 & 3202.000 & 3205.000 & 3202.000 & 3202.000 & 3200.000 \\
\hline Crude protein $(\%)$ & 23.000 & 23.000 & 23.000 & 23.000 & 20.000 & 20.000 & 20.000 & 20.000 \\
\hline Methionine (\%) & 0.540 & 0.540 & 0.540 & 0.540 & 0.390 & 0.380 & 0.380 & 0.380 \\
\hline Lysine (\%) & 1.310 & 1.310 & 1.310 & 1.310 & 1.180 & 1.180 & 1.180 & 1.180 \\
\hline $\mathrm{Ca}(\%)$ & 1.030 & 1.000 & 1.000 & 1.000 & 0.900 & 0.910 & 0.910 & 0.910 \\
\hline Available Phosphorus (\%) & 0.450 & 0.450 & 0.450 & 0.450 & 0.350 & 0.350 & 0.350 & 0.350 \\
\hline
\end{tabular}


American J. Animal \& Vet. Sci., 6 (2): 65-68, 2011

Table 2: Chemical composition of fermented ginger by-product

\begin{tabular}{lr}
\hline Chemical composition & $(\%)$ \\
\hline Gross energy $\left(\mathrm{kcal} \mathrm{kg}^{-1}\right)$ & 3905.00 \\
Dry matter & 87.44 \\
Crude protein & 7.29 \\
Crude fat 6 & 51.00 \\
Crude fiber & 22.10 \\
Crude ash & 13.40 \\
Calcium & 0.46 \\
Phosphorus & 0.84 \\
\hline
\end{tabular}

Table 3: Feed intake, body weight gain, ratio for 100 of control and feed efficiency of broilers in the control (Control) and in the 0.25 ( $0.25 \mathrm{~S})$, $0.5(0.5 \mathrm{~S})$ and $1 \%(1 \mathrm{~S})$ dietary Dried Fermented Ginger (DFG) from 7-42 days of age as well as in the $0.25(0.25 \mathrm{~F}), 0.5(0.5 \mathrm{~F})$ and $1 \%(1 \mathrm{~F})$ dietary DFG from 21 to 42 days of age (Mean \pm SEM, $n=5)$

\begin{tabular}{|c|c|c|c|c|c|c|c|}
\hline \multirow[b]{2}{*}{ Item } & \multicolumn{7}{|l|}{ Groups } \\
\hline & Control & $0.25 \mathrm{~S}$ & $0.5 \mathrm{~S}$ & $1 \mathrm{~S}$ & $0.25 \mathrm{~F}$ & $0.5 \mathrm{~F}$ & $1 \mathrm{~F}$ \\
\hline Feed intake $(\mathrm{g})$ & $3800 \pm 36.74$ & $3703.25 \pm 184.31$ & $3671.75 \pm 139.17$ & $3739.25 \pm 72.57$ & $3717 \pm 67.87$ & $3902.25 \pm 33.86$ & $3912.5 \pm 77.69$ \\
\hline Bodyweightgain (g) & $1874.25 \pm 40.28$ & $1841.25 \pm 14.27$ & $1908.25 \pm 54.89$ & $1889.75 \pm 33.39$ & $1926.25 \pm 43.46$ & $1958 \pm 44.73$ & $1945 \pm 49.06$ \\
\hline $\begin{array}{l}\text { Ratiofor } 100 \\
\text { index of control }\end{array}$ & 100 & 98.24 & 101.81 & 100.85 & 102.77 & 104.48 & 103.79 \\
\hline Feed efficiency & $0.49 \pm 0.01$ & $0.50 \pm 0.02$ & $0.52 \pm 0.03$ & $0.51 \pm 0.01$ & $0.52 \pm 0.01$ & $0.50 \pm 0.01$ & $0.50 \pm 0.01$ \\
\hline
\end{tabular}

$\mathrm{S}=$ Starter groups in which DFG was supplemented from 7-42 days of age. F = Finisher groups in which DFG was supplemented from $22-42$ days of age

\section{DISCUSSION}

For poultry farmers, it is very important to produce chicken meat cheaply without using chemicals. In the previous study, we obtained significantly increased body weight gain and feed efficiency in the $1 \%$ DFG group (Incharoen et al., 2010). However, in the present study, we failed to obtain a significant increase in body weight gain in the dietary DFG groups. There seems to be a correlation between this result and the high environmental temperatures and humidity in Thailand. The body temperature of adult chickens is normally in the range of $40-41^{\circ} \mathrm{C}$ and increased significantly when environmental temperatures increased (Donkoh, 1989). To optimize body weight gain and feed utilization for broilers, the environmental temperature should be near $21^{\circ} \mathrm{C}$ (Cooper and Washburn, 1998). In fact, it was found that there was a significant correlation with growth rate and the diurnal fluctuation in cloacal temperature (Cooper and Washburn, 1998) and that the growth rate and feed consumption of birds raised in higher environmental temperatures were depressed (Dei and Bumbie, 2011). Additionally, the present ginger (Zingiber officinale Roscoe) is known for its strong flavor and to have pyrogenicity (Eldershaw et al., 1992; Fujisawa et al., 2005). These might provide reasons why the present DFG groups did not show a dramatic body weight gain seen in warm area (Incharoen et al., 2010). However, the body weight gain of DFG groups did not decrease significantly than the control. This suggests that pyrogenicity of ginger in DFG had not a harmful influence on the body weight gain of birds raised in tropical and subtropical area. Rather, the body weight gain of DFG groups was better than that of the control, with the exception of the $0.25 \mathrm{~S}$ groups. Feed efficiency was also better in all the DFG groups than in the control; even the feed efficiency of the $0.25 \mathrm{~S}$ groups was better than the control. As DFG is a mixture of a fermented product of ginger and Japanese mugwort (Artemisia princeps Pamp.) silage juice, a little better growth performance of DFG groups than the control might be induced by that ginger stimulated gastric emptying ( $\mathrm{Hu}$ et al., 2011) and by that Japanese mugwort has qualities that improve the functioning of the immune system, the gastrointestinal tract and the liver (Swanston-Flatt et al., 1989; Umano et al., 2000). Besides, as the Japanese mugwort included natural microorganisms, such as lactic acid bacteria, yeast, photosynthetic bacteria, hyperthermal bacteria, Actinomycetes, Aspergillus and Bacillus subtilis (Incharoen et al., 2010), these probiotic also stimulate the intestinal function.

Compared to the starter groups, the body weight gain of the finisher groups showed a better value; this can ultimately contribute to reduced feed costs. For example, body weight gain of $0.5 \mathrm{~F}$ group is $4 \%$ higher than the control. Current price of broiler in Japan is about 3 dollar per kg. Therefore, one bird of $0.5 \mathrm{~F}$ group is 0.25 dollar higher than the control; 250,000 dollar will be made a profit in farmer rearing million broilers. Besides, the expensive cost of antibiotics can save it, too. 


\section{CONCLUSION}

DFG can apply to tropical and subtropical area as a natural supplementation without antibiotics and it is better to supplement to basal diet at $0.5 \%$ during finisher stage (from 22 days old), resulting in reduced feed cost.

\section{REFERENCES}

Aberra, M., S. Maak and G.V. Lengerken, 2005. The performance of naked neck and their F1 crosses with Lohmann White and New Hampshire chicken breeds under long-term heat stress conditions. Eth. J. Anim. Prod., 5: 91-107. PMID: 11432415

Ali, B.H., G. Blunden, M.O. Tanira and A. Nemmar, 2008. Some phytochemical, Pharmacological and toxicological properties of ginger (Zingiber officinale Roscoe): A review of recent research. Food Chem. Toxicol., 46: 409-420. DOI: 10.1016/J.FCT.2007.09.085

Andremont, A., 2000. Consequences of antibiotic therapy to the intestinal ecosystem. Ann Fr Anesth Reanim., 19: 395-402. PMID: 10874440

Atai, Z., M. Atapour and M. Mohseni, 2009. Inhibitory effect of ginger extract on Candida albicans. Am. J. Applied Sci., 6: 1067-1069. DOI: 10.3844/ajassp.2009.1067.1069

Butaye, P., L.A. Devriese and F. Haesebrouck, 2001. Differences in antibiotic resistance patterns of Enterococcus faecalis and Enterococcus faecium strains isolated from farm and pet animals. Antimicrob. Agents Chemother, 45: 1374-1378. DOI: 10.1128/AAC.45.5.1374-1378.2001

Castanon, J.I.R., 2007. Review: History of the use of antibiotics as growth promoters in European poultry feeds. Poult. Sci., 86: 2466-2471. DOI: 10.3382/ps.2007-00249

Cooper, M.A. and K.W. Washburn, 1998. The relationships of body temperature to weight gain, feed consumption and feed utilization in broilers under heat stress. Poult. Sci., 77: 237-242. PMID: 9495487

Darcan, N., F. Cedden and O. Guney, 2007. Spraying effects on goat welfare in hot and humid climate. Am. J. Anim. Vet. Sci., 2: 99-103. DOI: 10.3844/ajassp.2007.99.103
Dei, H.K. and G.Z. Bumbie, 2011. Effect of wet feeding on growth performance of broiler chickens in a hot climate. Br. Poult. Sci., 52: 82-85. DOI: 10.1080/00071668.2010.540230

Donkoh, A., 1989. Ambient temperature: A factor affecting performance and physiological response of broiler chickens. Int. J. Biometeorol., 33: 259265. DOI: $10.1007 / \mathrm{BF} 01051087$

Eldershaw, T.P., E.Q. Colquhoun, K.A. Dora, Z.C. Peng and M.G. Clark, 1992. Pigment principles of ginger (Zingiber officinale) are thermogeneic in the perfused rat hindlimb. Int. J. Obes. Relat. Metab. Disord., 16: 755-763. PMID: 1330955

Fujisawa, F., T. Nadamoto and T. Fushiki. 2005. Effect of intake of ginger on peripheral body temperature. J. Jpn. Soc. Nutr. Food Sci., 58: 3-9. ISSN: 02873516

Hu, M.L., C.K. Rayner, K.L. Wu, S.K. Chuah and W.C. Tai et al., 2011. Effect of ginger on gastric motility and symptoms of functional dyspepsia. World J. Gastroenterol., 17: 105-110. DOI: 10.3748/wjg.v17.il.105

Incharoen, T. and K. Yamauchi, 2009. Production performance, egg quality and intestinal histology in laying hens fed dietary dried fermented ginger. Int. J. Poult. Sci., 11: 1078-1085. DOI: 10.3923/ijps.2009.1078.1085

Incharoen, T., K. Yamauchi and N. Thongwittaya, 2010. Intestinal villus histological alternations in broilers fed dietary dried fermented ginger. J. Anim. Physiol. Anim. Nutr., 94: 130-e137. PMID: 20546067

Maak, S., A. Melesse, R. Schmidt and G.V. Lengerken, 2003. Effect of long-term heat exposure on peripheral concentrations of heat shock protein 70 (Hsp70) and hormones in laying hens with different genotypes. Br. Poult. Sci., 44: 133-138. DOI: $10.1080 / 000716603103214240$

NRC, 1994. Nutrient Requirement of Poultry. 6th End., National Academy Press, Washington DC, ISBN: 0309018617, pp: 54.

Swanston-Flatt, S.K., C. Day, P.R. Flatt, B.J. Gould and C.J. Bailey, 1989. Glycaemic effects of traditional European plant treatments for diabetes. Studies normal and streptozotocin diabetic mice. Diabetes Res., 10: 69-73. PMID: 2743711

Umano, K., Y. Hagi, K. Nakahara, A. Shoji and T. Shibamoto, 2000. Volatile chemicals identified in extracts from leaves of Japanese mugwort (Artemisia princeps pamp.). J. Agric. Food Chem., 48: 3463-3469. DOI: 10.1021/jf0001738 